\title{
材料の熱膨張の評価と制御
}

\author{
橋 本 拓 也 ${ }^{\mathrm{a}}$ \\ ${ }^{a}$ 日本大学 文理学部 物理学科 ( ₹ 156-8550 東京都世田谷区桜上水 3-25-40)
}

\section{Evaluation and Control of Thermal Expansion of Materials}

\section{Takuya HASHIMOTOa}

${ }^{a}$ Department of Physics, College of Humanities and Sciences, Nihon University(3-25-40 Sakurajousui, Setagaya-ku, Tokyo 156-8550)

Keywords : Thermal Expansion, Thermodynamics, Reduction Expansion, Measurement Method, Control of Thermal Expansion, Phase Transition

\section{1.はじめに}

材料を複合化して素子化する際には, 界面で発生する材料 間の機械的な相互作用の考慮が必要である。特に素子の作製 あるいは運転の際に温度変化があると, 材料の熱膨張挙動差 に起因するねじれ・割れなどが発生, 素子の特性に大きく影 響することがある ${ }^{1)}$ 。従って材料の熱膨張挙動の評価および 制御技術は, 素子の作製あるいは安定性向上のため重要となる。

本稿では熱膨張の起源と熱力学の関係, 熱澎張挙動の実験 的評価方法を紹介する。またこれまでに実施されている熱膨 張挙動制御の試行例も紹介する。

\section{2. 熱膨張あるいは熱収縮と熱力学}

物質の熱澎張挙動は, 基本的には体積あるいは長さの温度 依存性のデータが得られれば評価可能である。評価に用いら れる熱膨張係数は圧力を $P$, 温度を $T$, 物質の体積・長さを 各々 $V, L$ とすると, 偏微分を用いた以下の式で表される。

$$
\begin{aligned}
& \alpha=\frac{1}{V}\left(\frac{\partial V}{\partial T}\right)_{P} \\
& \beta=\frac{1}{L}\left(\frac{\partial L}{\partial T}\right)_{P}
\end{aligned}
$$

$\alpha$ を体積熱膨張係数, $\beta$ を線熱膨張係数と呼ぶ。これらの 值は理科年表を初め様々な文献で報告されているが, 使用に あたっては以下の注意が必要である。

(1)立方晶のように等方的な結晶構造をとる材料の場合は, $V=L^{3}$ より(1) および $(2)$ を用いると $\alpha=3 \beta$ が導出できる。 しかしながら正方晶や斜方晶など異方性を持つ結晶構造をと る材料の場合, 線熱膨張係数は方向によって異なる, いわゆ るテンソル量となり，必ずしも $\alpha=3 \beta$ は成立しない。また 3 . 2 で紹介する線熱膨張計で, 異方性のある物質の線熱膨張係 数を測定した場合は, 複数のテンソル量を平均した「ような」 值一もちろん試料の配向性によって得られる值が影響される 一が得られることとなり, 単結晶薄膜や配向薄膜と基板材料 との相互作用のように結晶成長方向まで問題となる場合, こ の值を用いるのは問題となる場合もある。
(2)熱澎張係数は温度に依存する。金属銅の例を図 $1^{2)} に$ 示す。 高温側で $\alpha$ が温度上昇に伴って漸増している。これは本物質 の熱膨張は, 温度上昇による格子振動の振幅の増大を起源と するものであるが, 高温領域では振幅の増大が温度に対して 線形に増大しなくなるためと説明できる。また低温では $\alpha$ が 急減し 0 に近づいている。これは熱力学第 3 法則に因るもの と説明可能であるが, 詳細は文献 ${ }^{2)}$ 参照されたい。これら $\alpha$ の変化する温度や $\alpha$ の温度依存性は物質によって異なる。 従って理科年表を初めとするデータベースには各種物質の熱 膨張係数が記載されているが, その值が適用可能な温度範囲 には十分注意する必要がある。場合によっては文献值があっ ても, 合成・使用温度範囲によっては自分で熱澎張係数を測 定する必要がある。

(3)熱膨張の起源の一つとして温度による格子振動の活性化 が挙げられるが, 高温かつ特に低酸素分圧下では, その他に 酸素不定比性の発生による膨張も知られている。これを「化 学膨張」あるいは「還元膨張」と呼ぶ。例として高温電気炉 のヒーター材料あるいは固体酸化物形燃料電池のインターコ ネクター材料として使用されていた $\mathrm{La}_{1-x} \mathrm{Ca}_{x} \mathrm{CrO}_{3-\delta}(x=0.1$ 〜0.3)の場合 ${ }^{3)}$ 紹介する。

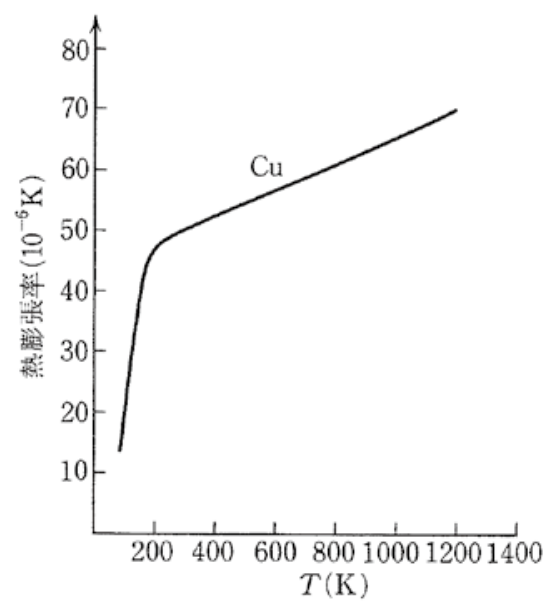

図 1 金属銅の体積熱膨張率の温度依存性 ${ }^{2}$ 
本物質は絶縁体である $\mathrm{LaCrO}_{3}$ の $\mathrm{La}^{3+}$ サイトに $\mathrm{Ca}^{2+}$ を部分 置換してホールによる電気伝導を持たせたものである。空気

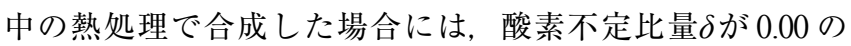
$\mathrm{La}_{1-x} \mathrm{Ca}_{x} \mathrm{CrO}_{3}$ が得られる。また酸素ガスあるいは空気中では 室温から $1000{ }^{\circ} \mathrm{C}$ ま゙ $\delta$ 発生せず, 温度に対してほぼ線形の 熱膨張挙動が得られる。しかしながら本物質を固体酸化物形 燃料電池のインターコネクターとして使用する場合には, $\mathrm{H}_{2}$ ガス下のような低酸素分圧下・還元性の然料ガス下での物性 の情報が必要である。図 2 に $700 \sim 900{ }^{\circ} \mathrm{C}$ での $\mathrm{La}_{0.7} \mathrm{Ca}_{0.3} \mathrm{CrO}_{3-\delta}$ の格子定数・モル体積の酸素分圧依存性を示す。本デー夕は 3. 1 で説明するガス雲囲気制御装置付き高温 X 線回折測定によ り得られたものである。酸素分圧 $P\left(\mathrm{O}_{2}\right)$ が $10^{-10} \mathrm{~atm}$ 以上では, 格子定数・モル体積の両者ともに温度のみによって一定值に 決まる。 $\mathrm{H}_{2} / \mathrm{H}_{2} \mathrm{O}$ 混合ガスを用いて $P\left(\mathrm{O}_{2}\right)$ を $10^{-17} \mathrm{~atm}$ 以下に低 下させると, 同一温度でも $P\left(\mathrm{O}_{2}\right)$ の低下に伴う格子定数・モ ル体積の増大が観測される。 $\mathrm{La}_{0.7} \mathrm{Ca}_{0.3} \mathrm{CrO}_{3-\delta}$ の酸素不定比量 $\delta$ の温度 $P\left(\mathrm{O}_{2}\right)$ 依存性は平衡熱天秤により測定されており ${ }^{4)}$,

図 2 のデー夕と組み合わせると，「化学膨張」あるいは「還元 膨張」を反映して， $\delta$ とル体積にほぼ比例関係が成立するこ とがわかった。

「化学澎張」あるいは「還元膨張」の発生の起源としては, 酸素不定比量 $\delta$ 発生に伴う陽イオンの価数変化が挙げられ る。 $\mathrm{La}_{0.7} \mathrm{Ca}_{0.3} \mathrm{CrO}_{3-\delta}$ の場合, $\delta=0.00$ なら $\mathrm{La}^{3+}$ サイトへの $\mathrm{Ca}^{2+}$ の部分置換によりホールが注入されて $\mathrm{Cr}$ の平均価数が $3.3+$ となっている。 $\delta$ が発生すると $\mathrm{Cr}$ の価数が低下し， イ オン半径が増大したものと説明できる。最近, 筆者らは「化 学澎張」を評価する指標として化学膨張係数 $\varepsilon_{\text {chem. }}$ を

$$
\varepsilon_{\text {chem. }}=\frac{1}{L}\left(\frac{\partial L}{\partial \delta}\right)_{T, P}
$$

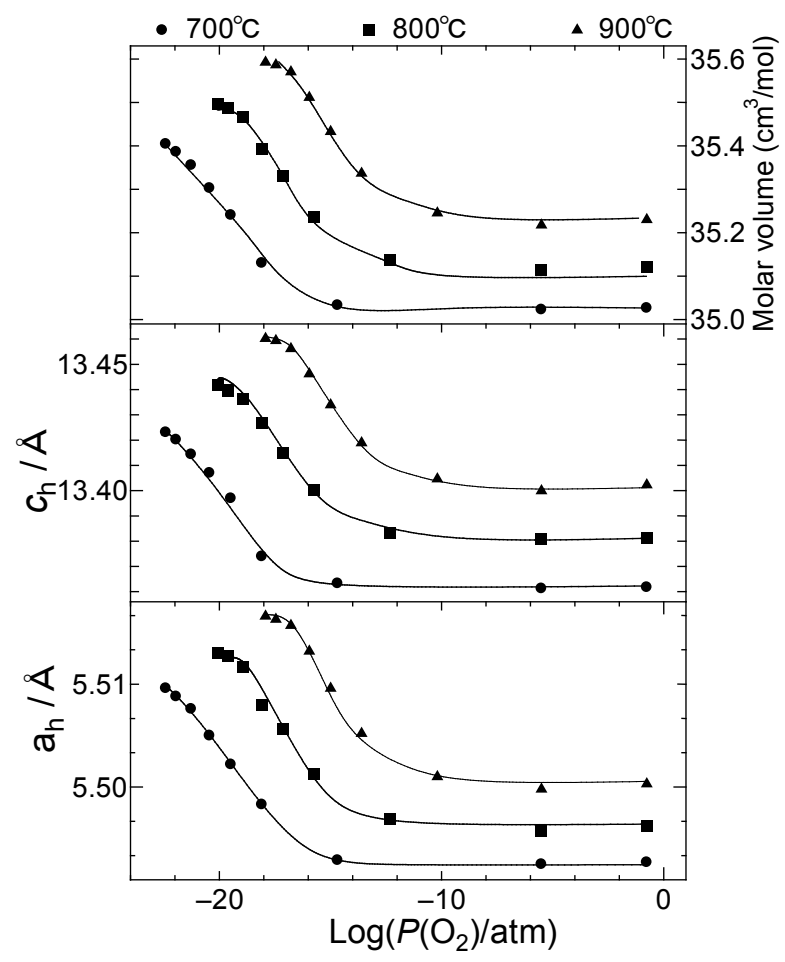

図 $2700 \sim 900{ }^{\circ} \mathrm{C}$ における $\mathrm{La}_{0.7} \mathrm{Ca}_{0.3} \mathrm{CrO}_{3-\delta}$ の格子定数・モル 体積の酸素分圧依存性 ${ }^{3)}$
と定義し, 固体酸化物形燃料電池材料について平衡熱天秤や 高温 X 線回折，熱膨張計での測定により算出した。詳細は 文献を参照されたい ${ }^{5)}$ 。

(4)温度・圧力などにより物質の状態が不連続に変化するこ とを「相転移」と呼ぶ。身近な例では水, 水, 水蒸気の変化 のように固・液・気相の変化が挙げられる。また斜方イオウ $\Leftrightarrow$ 単斜イオウなどの物質の結晶構造の温度変化あるいは温度 による鉄の強磁性 $\Leftrightarrow$ 常磁性の変化, 常伝導 $\Leftrightarrow$ 超伝導転移など も相転移の一つである。

相転移の起源は，物質のギブスエネルギー， $G$ が最小をと る形態が温度・圧力などにより変化することであり，これが 起こると $G$ の微分係数が不連続になる。この内, 1 次微分が 不連続になるものを「1 次相転移」，1次微分は連続に変化す るが，2 次微分が不連続になるものを「2 次相転移」と呼ぶ。 ギブスエネルギーの圧力および温度による微分で, 熱膨張に 関連するものは, 熱力学を用いた考察より以下のようになる ${ }^{6}$ 。

$$
\begin{aligned}
& \left(\frac{\partial G}{\partial P}\right)_{T}=V \cdots . \\
& \frac{\partial}{\partial T}\left(\frac{\partial G}{\partial P}\right)_{T}=\alpha V
\end{aligned}
$$

従って 1 次相転移では体積あるいは $V=L^{3}$ より長さ, 2 次 相転移では熱膨張係数が不連続に変化する。

図 3 に熱膨張計により 1 次相転移および 2 次相転移が観測 された例 ${ }^{7}$ を示す。 $\mathrm{Ba}_{2} \mathrm{In}_{2} \mathrm{O}_{5}$ は約 $910{ }^{\circ} \mathrm{C}$ で斜方晶ブラウンミ ラライトから歪んだぺロブスカイト構造への構造相転移を示 す。本温度で観測される急激な収縮, および熱澎張係数のピー ク状の変化は本相転移の次数が 1 次であることを示す。また 本物質は約 $1070{ }^{\circ} \mathrm{C}$ で熱膨張係数がシフトしているが, これ は対称性の高いペロブスカイト構造への 2 次相転移に対応す ることが高温 X 線回折の測定より解った。

以上のように相転移は材料の熱澎張挙動に大きく影響する ため，用途によっては問題となる場合がある。また相転移の 次数によって挙動が大きく異なるため, 次数の解析まで必要 となる場合もある。場合によっては相転移温度の制御を行う 必要が発生する場合もあり, 後述のカチオン部分置換はその 方法の一例である。この場合，カチオン分布が均一な試料が 合成できれば，相律の要請によって定圧下では相転移の温度

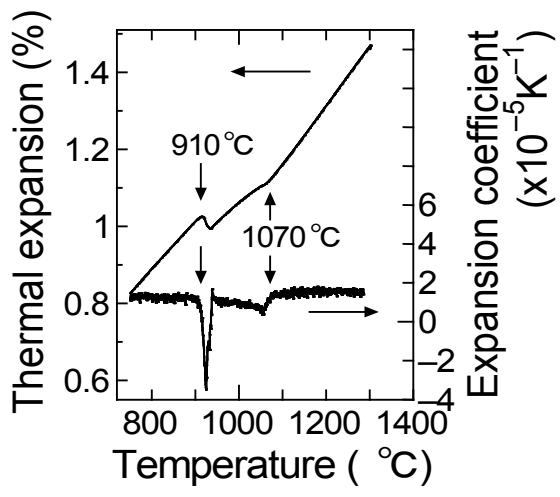

図 $3 \mathrm{Ba}_{2} \mathrm{In}_{2} \mathrm{O}_{5}$ の熱膨張挙動。9 $910{ }^{\circ} \mathrm{C}$ で一次構造相 転移に伴う熱膨張の不連続, $1070{ }^{\circ} \mathrm{C}$ で二次 構造相転移に伴う熱膨張の傾きの変化およ び熱膨張係数の不連続変化が観測される。 
がユニークに決まる。しかしながらカチオン分布が不均一な 試料では相転移温度がブロードとなるため, 現象論的には相 転移の温度付近で負や極めて低い熱膨張が観測されることが ある。このブロードな相転移により観測される負または低い 熱膨張を, 後述の純粋な格子定数の収縮あるいは変化が微少 であることによる熱収縮・ゼロ膨張と同様に扱ってよろしい か否かは議論が分かれるところである。

\section{3. 熱膨張挙動の測定方法}

材料の熱膨張挙動の測定は，基本的には体積あるいは長さ の温度依存性を測定するだけである。測定の様式として回折 を用いる方法または直接長さを測定する方法に分かれる。

\section{1 回折分光による熱膨張挙動の評価}

結晶質の物質では, 結晶系が判明していればX 線回折に より格子定数の測定が可能である。試料の温度を制御しなが ら回折測定を実施すれば，温度変化による回折シグナルのシ フトから格子定数の温度変化, つまり熱膨張挙動を測定する ことが出来る。高温あるいは低温に試料温度を制御してX 線回折測定が出来る装置は既に市販されており，最近は光軸 調整も簡単になってきたので，本手法による熱膨張評価の汎 用性が増してきている。本手法の利点を以下に記す。

(1)試料が多結晶体であっても格子定数を個別に測定するこ とが可能であるため, 熱膨張係数を方向性まで考慮した テンソル量として測定することが可能である。また基本 的には粉末測定であるため, 試料の焼結特性や試料内の 気泡の影響を受けない, 物性值としての熱澎張挙動を評 価することが可能である。

(2)後述の熱膨張計による測定と比較して, 試料の量が少な くて済む。

(3)測定時のガス種を制御, 酸素分圧などをモニターしなが らX 線回折を測定することも可能となってきており, 前述の「化学膨張」の測定がやりやすい。

(4)結晶構造の変化を伴う相転移を直接測定することが可能 であるため, 急激な体積変化や熱膨張挙動の不連続が あった場合，原因を特定できる場合が多い。

(5)リートベルト解析等で結晶学的パラメーターの温度依存 性まで評価できれば，化学物中のどの結合の結合長変化 が熱澎張の起源か? という学術的な考察まで実施するこ とが可能である ${ }^{8), 9)}$ 。

しかしながら本手法には以下の欠点もある。

(1)結晶性のない, ガラスのような物質では回折シグナルが 出現しないため，本手法は適用不可である。

(2)回折装置自体が高価である。特に温度可変やガス雲囲気 制御下で回折測定をするためには，さらに高価なオプ ションが必要となる。

(3)シグナルの回折角 (ブラッグ角)の測定にはある程度の時 間を要する場合が多いため, 温度を連続的に変化させる 測定には不向きであることが多い。従って熱膨張係数を 高精度で測定することは難しい。最近, 二次元検出器な どを用いて高速で回折角を測定することが可能となって きており，本問題点を克服できる可能性が出てきている。 (4)化合物中の化学結合長の温度変化を測定したい場合, 軽
元素と重元素間の結合距離, 特に酸化物中での酸化物イ オンとカチオンの距離, の精密な解析には X 線回折で はなく, 中性子回折が必要となる。必然的に測定に汎用 性はなくなってしまう。これは電子数の少ない軽元素の 原子パラメーターは, X 線回折では精密に測定出来ない ことに因る。

\section{2 長さを直接測定する方法}

本手法は温度を変化させながら試料の長さを直接測定する 方法である。一般的な押棒式熱膨張計の概念図を図 4 に示す。 自立可能 (円筒形では底面の直径が $5 \mathrm{~mm}$, 直方体状では $4 \mathrm{~mm}$ 角程度) な長さ 10 ～ $20 \mathrm{~mm}$ の試料をアルミナあるいは シリカ製のホルダーに設置し，アルミナあるいはシリカ製の 棒を反対側から荷重をかけてセットする。荷重は低すぎれば 測定值が安定せず，高すぎれば測定中に試料にめり込むこと があるので，適切な值にセットすることになる。この值は試 料および測定温度範囲によって異なるので，場合によっては 測定を複数回実施して最適化しなくてはならない。

固体試料の場合, 線熱膨張係数は高くても $10^{-5} \mathrm{~K}^{-1}$ のオー ダーである。従って $10{ }^{\circ} \mathrm{C}$ 温度変化させた場合, $10 \mathrm{~mm}$ の試 料では膨張は長くても $1 \mu \mathrm{m}$ となる。この程度の值を直接測 定するのは難しいので，多くの場合は図4のように試料と 同程度の長さの標準物質を試料近くにセットし, 試料と標準 試料の長さの差分を検出し, 電気回路で増幅してモニターす るようにしている。真の熱膨張は，差分より測定された「見 かけの熱澎張」から標準物質の熱膨張挙動を差し引いて算出 している。従ってアルミナを標準物質・押棒・ホルダー材料

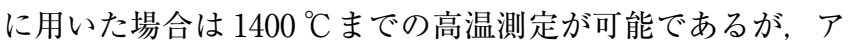
ルミナ自身の熱膨張係数が高いため, 熱膨張係数の測定值の 精度は落ちてしまう。それに対してシリカはアルミナより熱 膨張係数が低いため，測定材料に用いた場合，高精度な測定 が可能となる。しかしながらシリカは $1000{ }^{\circ} \mathrm{C}$ を越えると変 質するため，アルミナを用いた場合よりも温度範囲が低温に 限られる。本手法の利点を次に記す。

(1)測定装置が回折測定に比べて安価である。

(2)ガラスなど非晶質材料の熱膨張挙動も測定可能である。

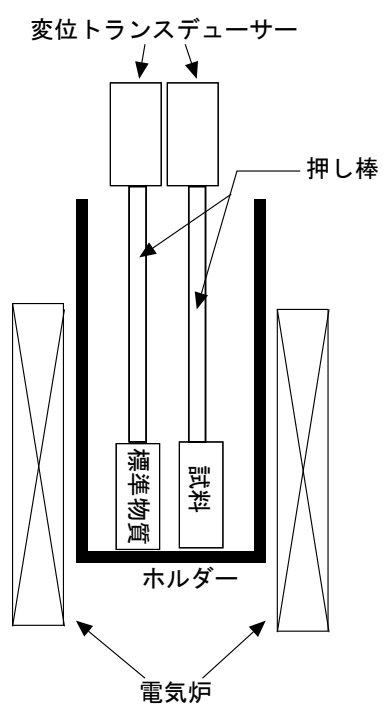

図 4 押棒式熱膨張計の概念図 
(3)温度を連続的に変化させて測定することが可能であり， 熱澎張係数の測定精度が高い。

(4)ガスフローさせながら測定することが可能であるので, 前述の「化学膨張」「還元膨張」の評価も出来る ${ }^{5)}$ 。

欠点としては

(1)試料としては例えば直径 $5 \mathrm{~mm} \phi て ゙$ 高さ $10 \mathrm{~mm}$ 程度のも のが必要であり，回折測定より大量の試料が必要である。 また粉末状では測定不可であり, 焼結などで塊状にする 必要がある。

(2)焼結体などでは内部の気泡，密度等により測定值が影響 される可能性がある。得られた值が物性值であるか否か の判定には慎重な検討が必要である。

(3)柔らかい試料では, 押棒の荷重が高すぎると測定中に試 料に食い込み, 信頼できるデータが得られないばかりで なく, 試料あるいは装置を壊す可能性がある。

(4)高温での測定の場合, 押棒・ホルダーと試料が化学反応 してしまう場合がある。これは装置を壊す原因となるこ ともある。防止のためには反応しない薄板状物質を試料 と押棒・ホルダーに挿入するのが効果的である。

(5)測定試料の殆どが多結晶体であるため, 体積熱膨張係数 は測定不能である。等方的な物質なら, 測定した線熱膨 張係数から $\alpha=3 \beta$ を用いて類推することは可能であるが, 異方性のある物質ならば類推は不可能な場合もある。

(6)主に多結晶物質の測定であるため, 熱膨張率をテンソル 量として評価するのは本手法では不可能である。単結晶 を用いて結晶方向に沿って線熱膨張挙動を測定すればテ ンソル量としての評価は原理的には可能であるが, 本手 法が適用可能な大きさを持つ単結晶を合成するのは至難 の技である。

(7)標準物質との熱膨張差を測定することになるため，標準 試料より熱澎張の小さい物質の測定を高精度で実施する のは難しい。

が挙げられる。(1)，(6)よび(7)の欠点を克服するには，短 い試料でも熱膨張が測定できるように, 試料長を高精度で測 定すれば良い。レーザー熱膨張計は, レーザー光の干渉を用 いて試料長を直接測定するものであり，公称分解能が $\mathrm{nm}$ オーダーであるため, 小形試料の熱膨張測定や高精度熱膨張 测定が可能と期待されている ${ }^{10)}$ 。筆者らも核融合材料 $\mathrm{Li}_{2} \mathrm{TiO}_{3}$ が $450{ }^{\circ} \mathrm{C}$ を境に熱膨張係数が微少変化することを レーザー熱澎張計により明らかにすることに成功した ${ }^{11)}$ 。 しかしながら本装置は高価であること, レーザー光の干渉を クリアに観測する必要があるため, 測定が $\mathrm{He}$ ガス中に限ら れること, 温度範囲が $500{ }^{\circ} \mathrm{C}$ 以下に制限されることなどの欠 点もある。

\section{4. 熱膨張挙動の制御方法}

熱膨張挙動を制御する技術としては(1)負の熱膨張を持つ物 質との複合化による低熱膨張材料の開発や(2)相転移温度を制 御し，使用温度範囲から相転移を解消することが挙げられる。 以下にこれらを紹介する。

\section{1 材料の複合化による熱膨張挙動の制御}

材料の熱澎張を低減化したい場合，考えられるのが負の熱
膨張を示す材料との複合化である。負の熱膨張を幅広い温度 範囲 $(0.9 \mathrm{~K} \sim 1050 \mathrm{~K})$ で示す物質として $\mathrm{ZrW}_{2} \mathrm{O}_{8}{ }^{12), 13)}$ が挙げ られる。本物質は $\mathrm{ZrO}_{6}$ 八面体と $\mathrm{WO}_{4}$ 四面体の連結から構成 され, 蛍石 $\left(\mathrm{CaF}_{2}\right)$ 型構造と類似した結晶構造をとる。蛍石の $\mathrm{Ca}^{2+}$ の位置を $\mathrm{ZrO}_{6}$ 八面体, $\mathrm{F}^{-}$の位置を $\mathrm{WO}_{4}$ 八面体が占め, 傾きながら頂点連結をしている。回折測定の結果, 昇温に伴っ て八面体および四面体は膨張するものの，傾きの解消も同時 に起こり，隙間を狭くしていくため，全体の結晶格子の大き さは小さくなることが解っている。線熱膨張係数は $-8.6 \times$ $10^{-6} \mathrm{~K}^{-1}$ に達するため, 本物質と複合化できれば様々な物質 の熱膨張係数を低減化できることが期待される。

筆者のグループでは光ファイバーのフェルル材料として使 用されている $\mathrm{ZrO}_{2}$ の熱澎張の低減化を目指して $\mathrm{ZrW}_{2} \mathrm{O}_{8}$ と の共焼結を試みた。 $\mathrm{ZrW}_{2} \mathrm{O}_{8}$ の融点が約 $1250{ }^{\circ} \mathrm{C}$ であため焼 結温度が上げられず，焼結密度および強度には問題が残った ものの, $\mathrm{ZrW}_{2} \mathrm{O}_{8}$ 量の増大に伴って熱膨張率が低下, $\mathrm{ZrO}_{2} /$

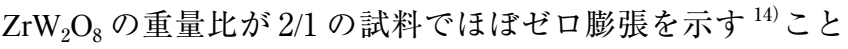
を明らかにした。この共焼結体の合成および熱膨張制御は

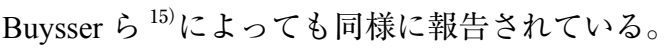

またTani ら ${ }^{16)}$ はレジンに $\mathrm{ZrW}_{2} \mathrm{O}_{8}$ 粉末をフィラーとして 混合したところ, 図 5 のようにフィラーの量の増大に伴い, 熱澎張が低減されることを報告している。

材料を複合化した場合, 熱膨張係数がどのようになるかに ついては様々なモデル式が提案されている。最も単純なもの が熱澎張によって発生する応力が至るところで一定であるこ とを仮定している ROM (Rule of mixture) モデルであり，以 下の式で複合材料の熱膨張 $\alpha_{c}$ が表される。

$$
\alpha_{c}=\alpha_{f} \phi+\alpha_{m}(1-\phi)
$$

ここで $\alpha_{f}, \alpha_{m}$ は各々フィラー, マトリックスの熱膨張係数, фはフィラーの体積分率である。このモデルが成立すれば 各々の熱澎張係数が判明していれば体積分率のみで複合材料 の熱澎張係数を制御することは可能であるが, 全ての複合材 料についてこのモデルが成立するわけではない。熱応力に代 わって，熱歪みが複合材料中で均一と仮定する Turnerのモ デル ${ }^{17)}$ では以下の式が成立する。

$$
\alpha_{c}=\frac{\alpha_{f} E_{f} \phi+\alpha_{m} E_{m}(1-\phi)}{E_{f} \phi+E_{m}(1-\phi)}
$$

ここで $E_{f}, E_{m}$ は各々フィラー, マトリックスのヤング率 である。このモデルが適用可能か否かの検討のためには, 各々 のヤング率のデータが必要となる。

複合体の熱膨張の制御には，まず ROM モデルあるいは Turner モデルが検討されるが，これらは熱応力あるいは熱歪 みが均質という極端な仮定をしているので，実際には中間的 なものである Shi のモデル ${ }^{18)}$ ，やSchaperyのモデル ${ }^{19)}$ が検 討されることも多い。各々の詳細は文献に譲る。図 6 は Tani らが図 5 のデータからレジンと $\mathrm{ZrW}_{2} \mathrm{O}_{8}$ の複合材料の熱膨張 を算出し, 上記のモデルで説明可能か否かを検討したもので ある。 ${ }^{16)}$ 実測された熱澎張係数の体積分率依存性は, ROM モデルと Turner モデルの中間の挙動をとり, Schaperyのモ デルを用いると説明可能と結論している。

\section{2 部分固溶による使用温度範囲からの相転移の解消}

$\mathrm{Al}_{2}\left(\mathrm{WO}_{4}\right)_{3}$ は $\mathrm{AlO}_{6}$ 八面体と $\mathrm{WO}_{4}$ 四面体の連結により構成 
され，室温では斜方晶をとる物質である。本物質の多結晶焼 結体を作製し熱膨張計により線熱澎張特性を測定したところ， 図 7 の下のデータが得られた ${ }^{20)}$ 。 $-11{ }^{\circ} \mathrm{C}$ から $300{ }^{\circ} \mathrm{C}$ の平均 の熱膨張係数は- $3.7 \times 10^{-7} \mathrm{~K}^{-1}$ とゼロ膨張に極めて近いこ とが判明，本物質が光ファイバーのフェルルなどゼロ膨張が 必要な用途に応用可能なことが期待された。しかしながら本 用途のためには - $50{ }^{\circ} \mathrm{C}$ から $200{ }^{\circ} \mathrm{C}$ ま゙ゼロ膨張であること が要求される。改めて熱膨張計の結果を見ると, $-130{ }^{\circ} \mathrm{C}$ か ら- $22{ }^{\circ} \mathrm{C}$ の範囲では $7.8 \times 10^{-6} \mathrm{~K}^{-1}$ と正の熱膨張を示すこ と, $-22{ }^{\circ} \mathrm{C}$ から $-11{ }^{\circ} \mathrm{C}$ では急膨張することが観測されてい た。回折測定 ${ }^{21,22)}$ の結果, 本物質は $-22{ }^{\circ} \mathrm{C}$ 以下では単斜晶 に歪んでおり温度上昇に伴ってモル体積が増大すること, $-22{ }^{\circ} \mathrm{C}$ から $-11{ }^{\circ} \mathrm{C}$ で観測された急膨張は斜方晶への 1 次構 造相転移のためであること, 斜方晶では温度上昇に伴うモル 体積の変化が極めて小さいことが解った。本相転移の次数が 1 次であることは図 7 の上に掲載した DSC（走査型熱量測定）

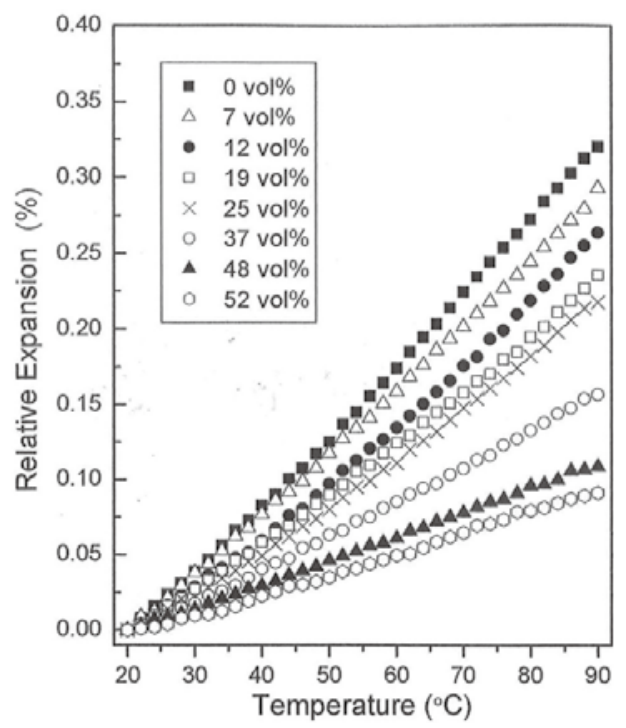

図 5 レジンに $\mathrm{ZrW}_{2} \mathrm{O}_{8}$ をフィラーとして加えた 複合体の熱膨張挙動。16)

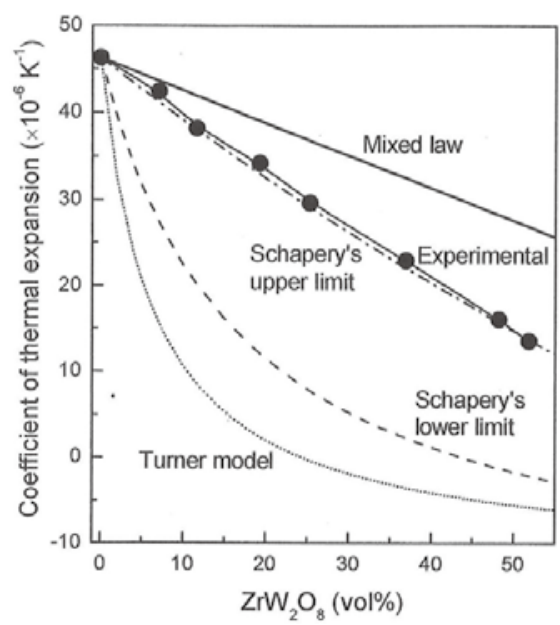

图 6 レジンに $\mathrm{ZrW}_{2} \mathrm{O}_{8}$ をフィラーとして加え た複合体の熱膨張係数の実測值，および ROM モデル, Turner モデル, Schapery のモデルでのシュミレーション ${ }^{16)}$
の結果で, 同温度で約 $390 \mathrm{~J} / \mathrm{mol}$ の吸熱に対応するピークが 観測されたことからも確認された。この相転移は，本物質を 例えば光ファイバーのフェルル材料として使用する場合，大 きな障害となる可能性があるため, 応用のためには - $50{ }^{\circ} \mathrm{C}$ 以下に相転移温度を変化させ， - 50 〜 $200{ }^{\circ} \mathrm{C}$ ではゼロ膨張 となるようにすることが必要である。

材料の構造相転移温度の制御方法としてはカチオンの部分 置換が知られている。例えば $\mathrm{LaCrO}_{3}$ は $260{ }^{\circ} \mathrm{C}$ 付近で斜方晶 ペロブスカイトから菱面体晶ペロブスカイトに構造相転移し, 急激な体積減少を示す。本物質の $\mathrm{La}$ サイトに $\mathrm{Ca}$ イオンあ

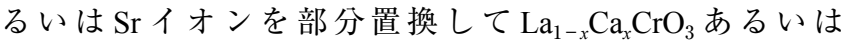
$\mathrm{La}_{1-x} \mathrm{Sr}_{x} \mathrm{CrO}_{3}(x=0.0 \sim 0.3)$ を合成すると, 導電特性・焼結 特性ばかりでなく構造相転移温度も変化する。Ca置換した 試料では相転移温度は上昇, Sr 置換した試料では下降する。 また $\mathrm{Ca} と \mathrm{Sr}$ を重置換した $\mathrm{La}_{1-x-y} \mathrm{Ca}_{x} \mathrm{Sr}_{y} \mathrm{CrO}_{3}$ の構造相転 移温度は $\mathrm{Ca}$ 組成 $x$ と $\mathrm{Sr}$ 組成 $y$ を用いて線形近似した式から 求められる值とほぼ一致する ${ }^{23)}$ 。

$\mathrm{Al}_{2}\left(\mathrm{WO}_{4}\right)_{3}$ でも同様にカチオンの部分置換により相転移温 度が制御可能か否かの検証 ${ }^{20)}$ を実施した。置換イオンとし ては $\mathrm{Al}^{3+}$ と同じ価数をとる $\mathrm{Y}, \mathrm{Ga}, \mathrm{Sc}$ を試した。まず $\mathrm{Y} の$ 部分置換を試みたところ, $\mathrm{Al}$ が rich な $\mathrm{Al}_{2-x} \mathrm{Y}_{x}\left(\mathrm{WO}_{3}\right)_{4}$ 相と $\mathrm{Y}$ が rich な $\mathrm{Y}_{2-x} \mathrm{Al}_{x}\left(\mathrm{WO}_{3}\right)_{4}$ 相に 2 相分離し, 部分置換はでき なかった。熱膨張挙動も相分離に対応して, 相転移に伴う急 膨張が 2 箇所の温度で観測された。

$\mathrm{Al}_{2-x} \mathrm{Ga}_{x}\left(\mathrm{WO}_{4}\right)_{3}$ は $\mathrm{Ga}$ 量 $0.0 \sim 0.4$ まで単相合成可能であっ たが, $x$ が 0.2 以上の試料では室温で単斜晶であった。これ は単斜晶から斜方晶への相転移温度が $\mathrm{Ga}$ 置換によって高温 となったためと結論でき, 熱膨張測定の結果とも対応, 一 50 ～ $200{ }^{\circ} \mathrm{C}$ の温度範囲から相転移を解消することはできな かった。

$\mathrm{Al}_{2-x} \mathrm{Sc}_{x}\left(\mathrm{WO}_{4}\right)_{3}$ は全率固溶体を形成, つまり全ての $x$ で斜 方晶単相の固溶体合成が可能であった。熱膨張測定の結果を 図 8 に示す。 $x=0.0$ 〜 0.3 では単斜晶から斜方晶への結晶 構造相転移に伴う急膨張が観測されたが，その温度は $\mathrm{Sc}$ 組 成の増大に伴って低下し $x=0.2$ では $-50{ }^{\circ} \mathrm{C}$ 以下となった。 また斜方晶の平均線熱膨張係数を $100 \sim 400{ }^{\circ} \mathrm{C} ，-50 \sim$

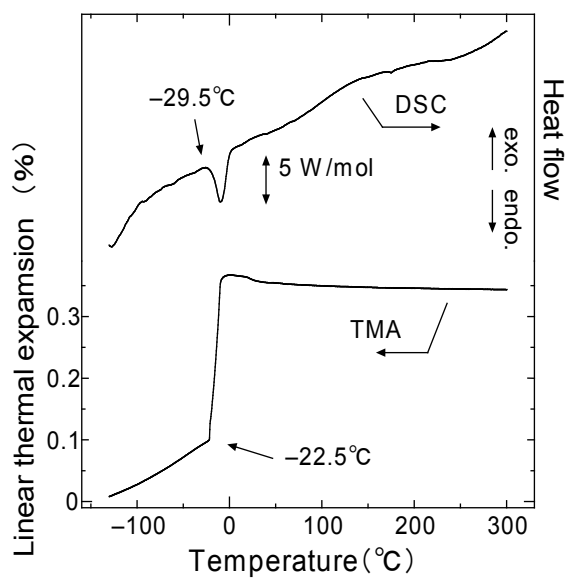

図 $7 \mathrm{Al}_{2}\left(\mathrm{WO}_{4}\right)_{3}$ の熱膨張挙動(下)および走 査型熱量測定の結果 $\left(\right.$ 上 ${ }^{20}$ 
$100{ }^{\circ} \mathrm{C}$ の範囲で算出した結果を図 9 に示す。データは相転移 フリーの温度領域で算出した。高温領域ではゼロ膨張が $x=$ 0.1 および $x=1.3$ 〜 1.5 で観測された。また $x=1.5$ で低温 領域でゼロ膨張が観測され, 新たなゼロ膨張材料の探索に成 功したものと筆者は考えている。しかしながら Sc は非常に 高価であるため, 実用化のためにはさらなる探索が必要と考 えられる。

\section{5. 結言にかえて}

本稿では熱膨張係数の定義，データベースを用いる場合の 注意点, 酸素不定比量や相転移による影響など熱力学との関 連を述べた。また自身で熱膨張係数を測定できるようになる ために, 測定方法の詳細・注意点を紹介した。さらに負の熱 膨張を示す材料を用いた熱膨張制御の試み，相転移温度制御 によるゼロ膨張材料の探索などを紹介した。もちろん負の熱 膨張材料や低熱膨張材料，またそれらの探索指針には，本稿

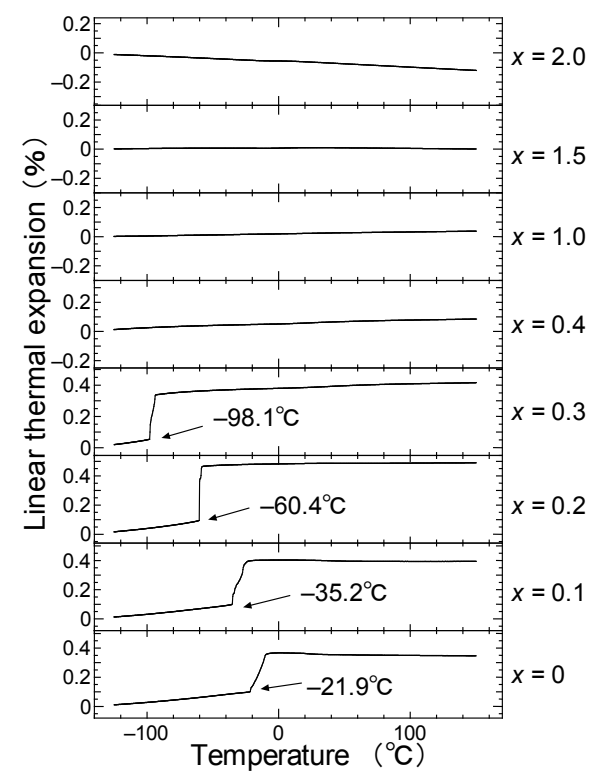

図 $8 \mathrm{Al}_{2-x} \mathrm{Sc}_{x}\left(\mathrm{WO}_{4}\right)_{3}$ の熱膨張挙動 ${ }^{20)}$

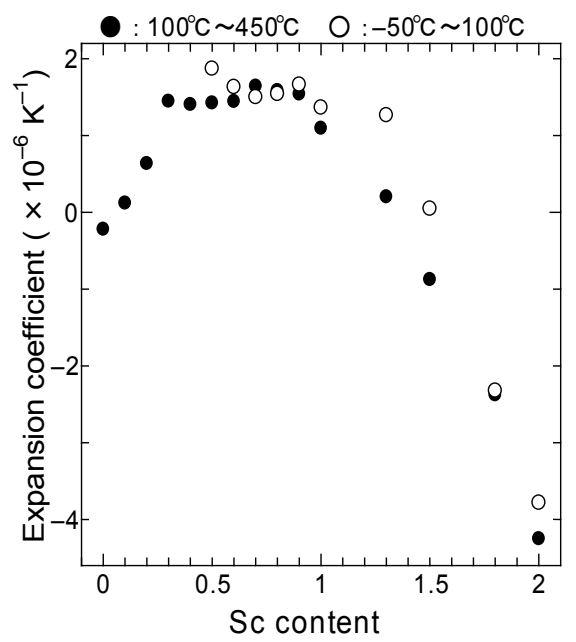

図 $9 \mathrm{Al}_{2-x} \mathrm{Sc}_{x}\left(\mathrm{WO}_{4}\right)_{3}$ の平均熱膨張係数 ${ }^{20)}$
では紹介しきれなかったものも多くある。また熱膨張と界面 の安定性の定量的な関連は非常に重要ではあるが, 筆者の力 不足で本稿では紹介することができない。本特集号では適材 適所な執筆者が上記の事項を紹介されるとのことであり，本 稿がその一部となれば幸いである。

なお本稿で使用したデー夕は筆者との共同研究者である丹 羽 栄貴 博士 (現東工大助教), 杉本 隆之 博士 (現日大助手) を 中心とする日本大学文理学部物理学科のメンバー, および現 U-VIX 株式会社代表取締役社長 ・ 森戸 祐幸 博士との共同研 究によるものである。特に森戸博士には熱膨張測定装置の入 手など研究費の面でもサポートをいただいた。謹んで感謝申 し上げる。

(Received December 25, 2015)

\section{文献}

1 ) T. Hashimoto, K. Fueki, A. Kishi, T. Azumi, H. Koinuma ; Jpn. J. Appl. Phys., 27, L214 (1988).

2 ) 原島 鮮; 熱力学・統計力学, p.154 (倍風館, 2011).

3 ) N. Ohba, E. Oikawa, T. Hashimoto ; Defect and Diffusion Forum, 242244, 9 (2005).

$4)$ S. Onuma, K. Yashiro, S. Miyoshi, A. Kaimai, H. Matsumoto, Y. Nigara, T. Kawada, J. Mizusaki, K. Kawamura, N. Sakai, H. Yokokawa ; Solid State Ionics, 174, 287 (2004).

5 ) E. Niwa, T. Hashimoto ; Solid State Ionics, http://dx.doi.org/10.1016/ j.ssi.2015.09.019 (2015).

6 ) R. A. Swalin ; 固体の熱力学, p. 77 (コロナ社, 1992).

7 ) T. Hashimoto, Y. Ueda, M. Yoshinaga, K. Komazaki, K. Asaoka, S. Wang; J. Electrochem. Soc., 149, A1381 (2002).

8 ) K. Omoto, M. Yashima ; Appl. Phys. Express, 7, 037301 (2014).

9 ) K. Omoto, M. Yashima, J. R. Hester ; Chem. Lett., 43, 515 (2014).

10）前田幸男; Ulvac Technical Journal, 64, 5 (2006).

11) T. Hoshino, K. Tanaka, J. Makita, T. Hashimoto ; J. Nucl. Mater., 367$370,1052(2007)$

12) T. A. Mary, J. S. O. Evans, T. Vogt, A. W. Sleight ; Science, 272, 90 (1996).

13) J. S. O. Evans, T. A. Mary, T. Vogt, M. A. Subramanian, A. W. Sleight ; Chem. Mater, 8, 2809 (1996).

14) E. Niwa, S. Wakamiko, T. Ichikawa, S. Wang, T. Hashimoto, K. Takahashi, Y. Morito ; J. Ceram. Soc. Jpn., 112, 271 (2004).

15) K. D. Buysser, P. Lommons, C. D. Meyer, E. Bruneel, S. Hoste, I. Van Driessche ; Ceramics-Silikaty, 48, 139 (2004).

16) J. Tani, H. Kimura, K. Hirota, H. Kido ; J. Appl. Polymer Sci., 106, $3343(2007)$

17) P. S. Turner ; J. Res. Natl. Bur. Stand., 37, 239 (1946).

18) J. D. Shi, Z. J. Pu, K. -H. Wu, G. Larkins ; Mater. Res. Soc. Symp., 445, 229 (1997).

19) R. A. Schapery: J. Comput. Mater, 2, 380 (1968).

20) T. Sugimoto, Y. Aoki, E. Niwa, T. Hashimoto, Y. Morito ; J. Ceram. Soc. Jpn., 115, 176 (2007).

21) Y. Ogata, K. Tsuda, T. Hashimoto ; Jpn. J. Appl. Phys., 47, 4664 (2008)

22) T. Hashimoto, T. Sugimoto, K. Omoto, N. Kineri, Y. Ogata, K. Tsuda ; Phys. Stat. Sol.(B), 245, 2504 (2008).

23) A. Mitsui, K. Homma, Y. Kumekawa, F. Nakamura, N. Ohba, Y. Hoshino, T. Hashimoto ; J. Electrochem. Soc., 155, A395 (2008). 